\title{
Organic pollutant degradation of tapioca flour industrial waste with photo-fenton reaction
}

\author{
Alin Elita Esther Sarajar ${ }^{l}$, Refa Putri Ramadhania ${ }^{1}$, and Purwanto Purwanto ${ }^{1,2 *}$ \\ ${ }^{1}$ Department of Chemical Engineering, Faculty of Engineering, Universitas Diponegoro, Semarang, Indonesia \\ ${ }^{2}$ School of Postgraduate Studies, Universitas Diponegoro, Semarang, Indonesia
}

\begin{abstract}
Cassava (Manihot utilissima) is the main raw material of tapioca flour industry. The tapioca industry waste water still contains high enough BOD, COD, and cyanide, above the quality standard of industrial waste water. Photo-Fenton is one of the most effective alternative methods of degrading organic pollutants. This study aims to determine the effect of Photo-Fenton method on the degradation of organic pollutants such as $\mathrm{COD}$ and cyanide. For operating conditions of this study use the addition of concentrations of $\mathrm{H}_{2} \mathrm{O}_{2}$ and $\mathrm{FeSO}_{4} \cdot 7 \mathrm{H}_{2} \mathrm{O}$ and different UV light intensity. The analysis of COD concentration using SNI method is spectrophotometric. From the research result, it is found that the concentration of COD and cyanide in tapioca waste can be reduced by using Photo-Fenton method. With initial COD content of $6000 \mathrm{mg} / \mathrm{L}$ and cyanide level of $0.67 \mathrm{mg} / \mathrm{L}$. And in the operating conditions of the addition of $5 \mathrm{ml} / \mathrm{l}$ of $\mathrm{H}_{2} \mathrm{O}_{2}, \mathrm{Fe}^{2+} 1.25 \mathrm{mg} / \mathrm{l}$, and light intensity of $200 \mathrm{~lm}$, the highest COD and cyanide levels were found to be $900 \mathrm{mg} / \mathrm{l}$ for COD and $0.08 \mathrm{mg} / 1$ for cyanide. Final levels of COD up to $900 \mathrm{mg} / \mathrm{l}$ and cyanide concentrations up to $0.08 \mathrm{mg} / \mathrm{l}$.
\end{abstract}

\section{Introduction}

Tapioca industry is an industry that can be managed in many ways. It can be a small scale, medium scale, or even large scale industry. It also has a great potential in penetrating domestic and international market. The greatest domestic demand comes from some parts of Java Island, such as: Bogor, Tasikmalaya, and Indramayu. While the international demand comes from some of ASEAN countries and European countries. As for the industry itself, there are a lot of promising places in Indonesia, they are: Pati, Batang, Temanggung, Wonosobo, and DIY Yogyakarta.

In tapioca production, a lot of water is needed. Each ton of cassava needs 6-9 $\mathrm{m} 3$ water. The waste water of this process contains relatively high $\mathrm{COD}$ and cyanide. It has $6,000-10,200 \mathrm{mg} / 1$ for COD and $0.67 \mathrm{mg} / \mathrm{l}$ for cyanide. Based on Ministry of Environment (KLH) decree No. Kep-03/Men-KLH/II/1991, the waste water of the tapioca industry exceeds the standard quality of industrial water waste (which are $400 \mathrm{mg} / \mathrm{l}$ for COD and $0.5 \mathrm{mg} / \mathrm{l}$ for cyanide). Letting the waste water to a watercourse will reduce the oxygen in the water. As a result, microbes are starting to die and rot, which will pollute the environment with its smell. [1]

There is a poison known as hydro cyan or $\mathrm{HCN}$ in tuber flesh and cassava skin [2]. The poison does not stand alone. It is bonded in a glycoside cyanogenic chain. It contains glucose, acetone and HCN. The poison can be reduced, or even eradicated, by producing tapioca flour from the cassava. When the cassava is shredded, cells within the cassava will be broke, therefore the glycoside and $\mathrm{HCN}$ will be separated. This kind of method needs a lot of water and the water should be updated frequently. Thus the glycoside and cyanide are disposed as waste.

Fenton's reaction is one of the Advance Oxidation Process (AOPs) and one of the popular waste processing methods[3]. AOPs is a chemical and physical waste processing method which can lower COD and poisonous substance such as phenol and xylene. In addition, AOPs can reduce the levels of organic substance such as pesticide, surfactant, and pharmaceutical waste, which are difficult to be omitted. Whereas Photo-Fenton process is a development of Fenton's Process by adding ultraviolet light to accelerate and increase the formed hydroxyl radical [4].

\section{Materials And Methods}

\subsection{Materials}

Tapioca waste water, which is obtained from Tapioca Flour Home Industry in Margoyoso, Pati, Central Java is one of the materials that will be tested. Chemical materials used in this experiments are Fenton reagents such as $\mathrm{H}_{2} \mathrm{O}_{2}$ analytical grade $30 \% \mathrm{w} / \mathrm{w}$ and $\mathrm{Fe}_{2} \mathrm{SO}_{4} .7 \mathrm{H}_{2} \mathrm{O}$ analytical grade $99 \%$. Other substances used for $\mathrm{pH}$ regulator is $\mathrm{H}_{2} \mathrm{SO}_{4}$. Self-made COD Digestion Reagent based on Indonesian National Standard is used to analyze COD levels. Another material used in this experiment is 10 watt UV lamp with wavelength of 380-200 $\mathrm{nm}$ and its luminous intensity is $\pm 10 \mathrm{~lm} /$ watt.

\footnotetext{
* Corresponding author: p.purwanto@gmail.com
} 


\subsection{Methods}

All experiments concerning the application of the ultraviolet radiation were performed in a batch reactor. The schematic diagram of the experimental set-up used for these processes is shown in Fig. 1.

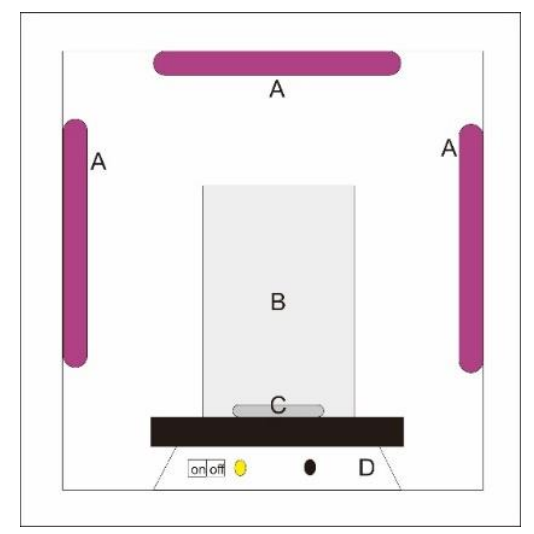

Fig. 1. Series of Experiments Tools. A-UV Lamp, B-Reaction Space (Beaker Glass), C-Magnetic Stirrer, D-Hot Plat Magnetic Stirrer.

Fig. 1 Reactor was cylindrical filled with 0.85 litre of wastewater and was made from quartz glass (used beaker glass) which was available for the transfer of the radiation. Irradiation was achieved by using UV lamp (10 W with wavelength of $200-280 \mathrm{~nm}$ and its luminous intensity is $\pm 10 \mathrm{~lm} /$ watt) which is placed above or beside the reactor. For Photo-Fenton processes, the reactor was filled with 0.85 liter of wastewater. The desired $\mathrm{pH}$ value was adjusted with sulfuric acid before start-up, and then a given weight of iron salt was added. The iron salt was mixed very well with the wastewater before addition of a given volume of hydrogen peroxide. For Photo-Fenton the time at which the UV lamp was turned on was considered the zero time, or the beginning of the experiment that was taking place simultaneously with injection of hydrogen peroxide and adding the dose of iron salt. The amount of reagent $\mathrm{FeSO}_{4} \cdot 7 \mathrm{H}_{2} \mathrm{O}$ and $\mathrm{H}_{2} \mathrm{O}_{2}$ designed for the experiment was added and homogenized by the magnetic stirrer [5]. This experiment investigated the effect of $\mathrm{H} 2 \mathrm{O} 2, \mathrm{Fe} 2 \mathrm{SO} 4$, and light intensity to the concentration of COD and cyanide in tapioca wastewater.

\section{Results and Discussions}

\subsection{The effect of initial $\mathrm{H}_{2} \mathrm{O}_{2}$ concentration on the degradation of COD concentration}

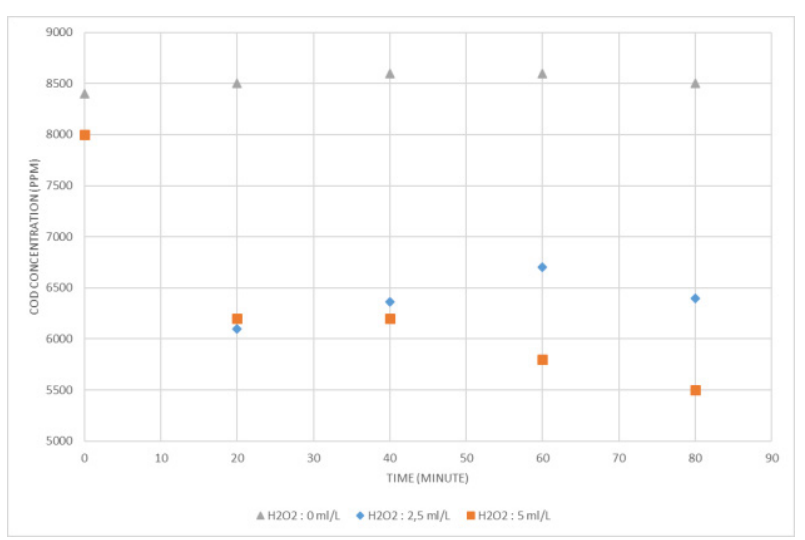

Fig. 2. COD concentration with various addition of hydrogen peroxide $\left(\mathrm{H}_{2} \mathrm{O}_{2}\right)$ graphic

Fig. 2 shows a decrease of COD over time. From all of the treatments, the highest percentage of RCOD in the concentration of $\mathrm{H}_{2} \mathrm{O}_{2}$ is $275 \mathrm{ppm}$ is $56.25 \%$, which happened in 80-minute treatment. Based on the graphic above, by using the $5 \mathrm{ml} / \mathrm{L} \mathrm{H}_{2} \mathrm{O}_{2}$ the COD level can be reduced, which it appears that the longer the reaction time, the greater the reduction. It means that the Photo-Fenton process can oxidize the organic compound in tapioca waste water.

Chemical oxidation can be defined as a process in which electrons move from one substance to the other [6]. The direction of electron's movement is determined by the oxidation potential. Oxidation potential is an oxidation power which come from oxidation reduction reaction, and it is represented in volt to normalize hydrogen electrode. Besides, hydrogen peroxide (H2O2) is a chemical oxidizing agent with the oxidation potential of $1.77 \mathrm{~V}$ which greater than permanganate $(1.67 \mathrm{~V})$ and chlorine $(1.36 \mathrm{~V})$ [7]. Thus, the oxidation power of hydrogen peroxide can break down organic compounds to simple compounds. The result of the research, the greater the concentration of $\mathrm{H} 2 \mathrm{O} 2$ the greater the reduction of COD $(\%$ RCOD) is, confirms the theory. However, excessive concentration of $\mathrm{H} 2 \mathrm{O} 2$ can make $\mathrm{H} 2 \mathrm{O} 2$ reacts with hydroxyl radical which produce perhydroxyl radical $(\cdot \mathrm{OOH})$ that has a lot less oxidation power than hydroxyl radical [8].

\subsection{The effect of $\mathrm{Fe}^{2+}$ weight ratio on the degradation of COD concentration}

The effectivity of Fenton reagents is needed to be observed in terms of $\mathrm{Fe} 2+$ concentration. Iron salt such as $\mathrm{Fe} 2+$ works as catalyst in Fenton process to convert $\mathrm{H} 2 \mathrm{O} 2$ to reactive hydroxyl radical. This phenomenon is shown on Fig. 3. 


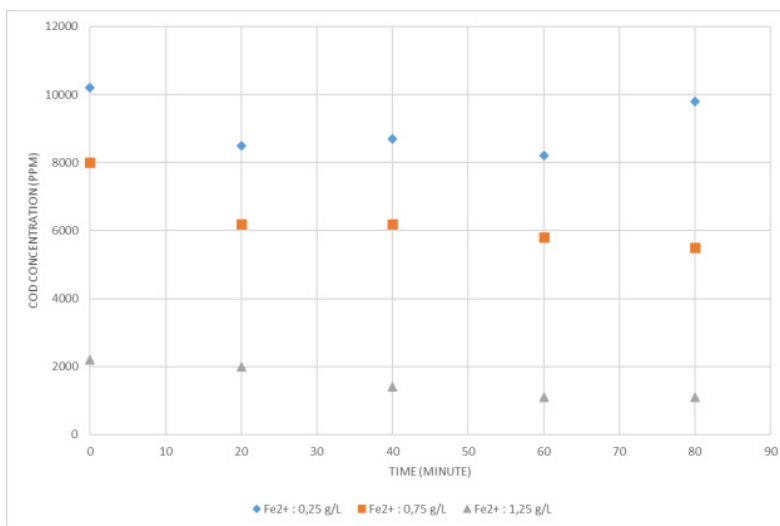

Fig. 3. COD Concentration with various addition of ferrous sulphate catalyst $\left(\mathrm{Fe}_{2} \mathrm{SO}_{4} \cdot 7 \mathrm{H}_{2} \mathrm{O}\right)$ graphic

Fig. 3 shows that the $\mathrm{Fe}^{2+}$ concentration of $1.25 \mathrm{~g} / \mathrm{l}$ can reduce COD concentration by $50 \%$, which is the highest percentage occurred in the experiment. The greater the ferrous sulphate concentration, the more oxidation of pollutants occurred, which is shown by the bigger decrease of liquid waste's COD level. This event happened due to the increasing number of hydroxyl radical formed [9].

Hydroxyl radicals (HO.) react swiftly and nonselective with almost all of electron-rich organic compound which can eradicate organic chemicals effectively. These radicals can mineralize some of the substrates, for instance: it can reduce substrates to $\mathrm{CO}$ and $\mathrm{H} 2 \mathrm{O}$ [10].

\subsection{The effect of luminous intensity on the degradation of COD concentration}

Based on Fig. 4 shown above, using 2 UV lamps is proved to reduce the COD concentration with the highest percentage of $70 \%$. There is not much difference between using 3 lamps and using 2 lamps. Hence, in order to reduce the COD concentration of tapioca waste, using 2 UV lamps are enough.

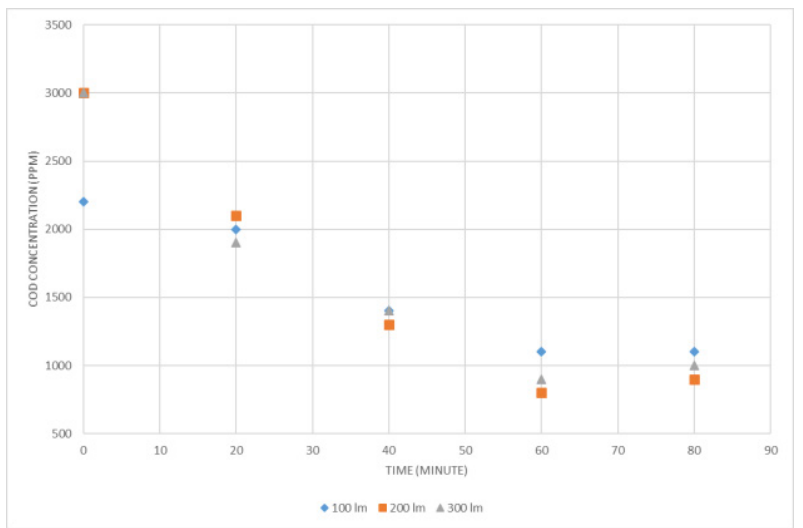

Fig. 4. COD Concentration with various intensity of UV lamp radiation graphic

The function of the combination between UV and oxidation, such as $\mathrm{H} 2 \mathrm{O} 2$, or catalyst is to produce hydroxyl radical $(\cdot \mathrm{OH})[11]$. As shown in the equation (2), a free radical has a very high potential $(2.8 \mathrm{~V})$. This radical is the one used to perfectly degrade gas organic pollutants such as $\mathrm{CO} 2$ and $\mathrm{H} 2 \mathrm{O}$. The degradation process is done by breaking bonds between atoms in dye molecules so that the molecules can be smaller, colorless and safe. In addition, a point in UV lamp's wavelength ( $\lambda$ $=254 \mathrm{~m}$ ) will be effective in killing bacteria.

Free radical formation rate in Fenton photo process is 6 times greater than in Fenton process. It means that there is a good catalytic activity and better formation of free radical generation $\left(\mathrm{OH}^{-}\right)$in Fenton photo process.

\subsection{The effect of Photo-Fenton process on the degradation of cyanide}

The test of cyanide content in tapioca liquid waste water was processed in optimal variable. At first, the cyanide content in the liquid waste is $0.67 \mathrm{mg} / \mathrm{l}$, then after processed by using Photo-Fenton methods, the cyanide content in the liquid waste is $0.08 \mathrm{mg} / \mathrm{l}$. Thereby, the Photo-Fenton methods decreased the cyanide content until $88.06 \%$.

The reason that the reduction seems significant is because the cyanide has reacted with hydrogen peroxide to form ion cyanate.

$$
\mathrm{H}_{2} \mathrm{O}_{2}+\mathrm{CN}^{-} \longrightarrow \mathrm{Fe}^{+} \mathrm{OCN}^{-}+\mathrm{H}_{2} \mathrm{O}
$$

As shown in the reaction above, hydrogen peroxide forms cyanate and water. It is a process that limit the forming of dissolved solids in a solution which being treated. Increasing the addition of hydrogen peroxide will make the greater amount of cyanide which will react to form ion cyanate. Thus, the free cyanide content in the liquid waste will be reduced. This condition occurred when there is a balance between the amount of hydrogen peroxide and the amount of cyanide in the liquid waste [12].

\subsection{Reaction Kinetics}

Kinetics of COD degradation in tapioca waste water is modelled by first order reaction. The relation between reaction time of Photo-Fenton and $\ln \left(\mathrm{C}_{0} / \mathrm{C}\right)$ in tapioca liquid waste is shown in Fig. 5, 6, and 7.

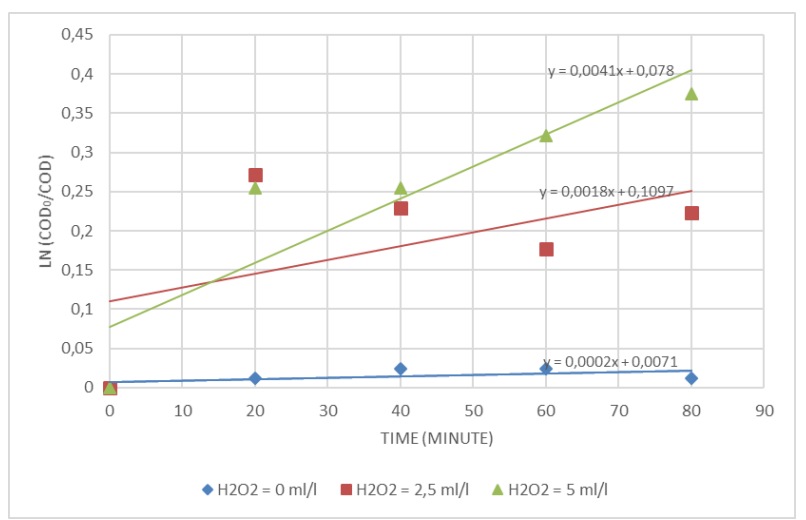

Fig. 5. The relation between reaction rate and $\ln \left(\mathrm{C}_{0} / \mathrm{C}\right)$ in various concentration addition of $\mathrm{H}_{2} \mathrm{O}_{2}$ graphic 


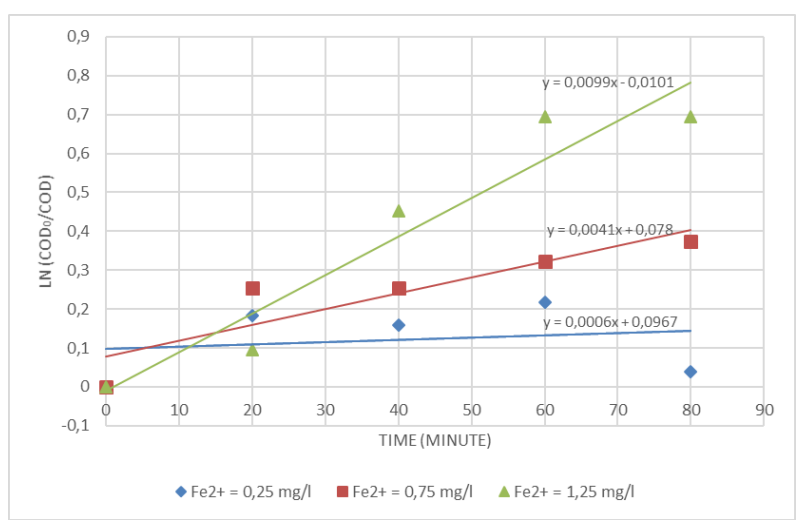

Fig. 6. The relation between reaction rate and $\ln \left(\mathrm{C}_{0} / \mathrm{C}\right)$ in various concentration addition of $\mathrm{Fe}^{2+}$ graphic

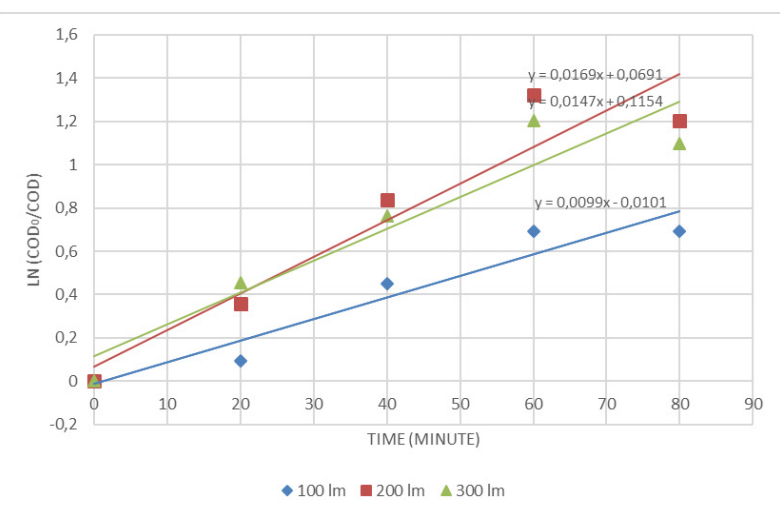

Fig. 7. The relation between reaction rate and $\ln \left(\mathrm{C}_{0} / \mathrm{C}\right)$ in various concentration addition of UV lamp radiation graphic

The rate constant of the Photo-Fenton reaction can be obtained from the graphs in the three figures above through the slope of the linear equation. The constants in each reaction system are shown in the Table below.

Table 1. C value in various operation condition in processing tapioca liquid waste using Photo-Fenton process

\begin{tabular}{|c|c|c|c|c|}
\hline \multirow{2}{*}{ Run } & \multicolumn{3}{|c|}{ Operation Condition } & \multirow{2}{*}{$\begin{array}{c}\text { C value } \\
\left(\mathrm{men}^{-1}\right)\end{array}$} \\
\cline { 2 - 4 } & $\begin{array}{c}\mathrm{C}_{\mathrm{H} 2 \mathrm{O} 2} \\
(\mathrm{~m} 1 / \mathrm{l})\end{array}$ & $\begin{array}{c}\mathrm{C}_{\mathrm{FeSO} 4} \\
(\mathrm{mg} / \mathrm{l})\end{array}$ & $\begin{array}{c}\text { Luminous } \\
\text { intensity }(\mathrm{lm})\end{array}$ & \\
\hline & 0 & 0.75 & 100 & 0.0002 \\
\hline 2 & 2.5 & 0.75 & 100 & 0.0018 \\
\hline 3 & 5 & 0.75 & 100 & 0.0041 \\
\hline 4 & 5 & 0.25 & 100 & 0.0006 \\
\hline 5 & 5 & 0.75 & 100 & 0.0041 \\
\hline 6 & 5 & 1.25 & 100 & 0.0099 \\
\hline 7 & 5 & 1.25 & 100 & 0.0099 \\
\hline 8 & 5 & 1.25 & 200 & 0.0169 \\
\hline 9 & 5 & 1.25 & 300 & 0.0147 \\
\hline
\end{tabular}

As shown in the Table above, the highest constant is $0.0169 \mathrm{men}^{-1}$ which is obtained in the experiment with the addition of $5 \mathrm{ml} / 1 \mathrm{H}_{2} \mathrm{O}_{2}, 1.25 \mathrm{mg} / \mathrm{l} \mathrm{Fe}{ }^{2+}$, and $200 \mathrm{~lm}$ luminous intensity of UV lamp. By adding UV lamp luminous intensity to $300 \mathrm{~lm}$, the constant value is 0.0147 $m^{-1}$. The lowest constant value occurred on the experiment which has the addition of $0.75 \mathrm{mg} / 1 \mathrm{Fe}^{2+}$ and $100 \mathrm{~lm}$ UV lamp luminous intensity.

\section{Conclusion}

The concentration of COD in tapioca waste water decreased from $6,000-10,200 \mathrm{mg} / 1$ to $900 \mathrm{mg} / \mathrm{l}$ by using Photo-Fenton reaction. Meanwhile the concentration of cyanide diminished by $88.06 \%$ from $0.67 \mathrm{mg} / 1$ to 0.08 $\mathrm{mg} / \mathrm{l}$.

\section{References}

1. L.J. Betty Sri, P.R. Winiati, Waste Management of Food Industry, Food and Nutrition Laboratory, Thesis of Institut Pertanian Bogor (1993)

2. Lies. Suprapti, Tapioca Flour: Making and Utilizing (Kanisius, Yogyakarta, ISBN 979-21-0854-8, 2005)

3. L. Zhou, J. Hu, X. Li, Chemical Engineering Research and Design, 90, 377-382, (2012)

4. M. Tokumura, H. T. Znad, Y. Kawase, Water Research 42, lB, 4665-4673, (2006)

5. E.E. Ebrahiem, M.N. Al-Maghrabi, A.R. Mobarki, Arabic Journal of Chemistry (2013)

6. M. Rodriquez, Thesis of Master Program, University of Bercelona, Departement of Engineering, (2003)

7. H. B. Hadjltaief, A. Sdiri, W. Ltaief, P.D. Costa, M.E. Gàlvez, M.B. Zina, Comptes Rendus Chimie xxx 110, (2017)

8. M. Ahmadi, F. Vahabzadeh, B. Bonakdarpour, E. Mofarrah, M. Mehranian, Journal of Hazardous Materials, B123,. 187 -195 (2005)

9. G.N. Achilleand L. Yilian, Journal of American Science 6, 4: 58-66, (2010)

10. J. M. P. Hernández, C. A. M. Huitle, J. L. G. Mar and A. H. Ramírez, Journal of Environmental Engineering Management 19, 5, 257-265, (2009)

11. S. S. Hutagalung, Jurnal Teknologi Pengolahan Limbah 13. No. 2, (2010)

12. M.M. Botz, Mining Journal, 28-30 (2001) 